\title{
Bibliography
}

For convenience's sake, Indonesian personal names are listed according to the last part of their name

Ajidarma, Seno Gumira

1997 Ketika jurnalisme dibungkam sastra harus bicara. Yogyakarta: Yayasan Bentang Budaya.

Anderson, Benedict R.O'G.

1990 Language and power; Exploring cultures in Indonesia. Ithaca/London: Cornell University Press. [The Wilder House series in politics, history and culture.]

1991 Imagined communities; Reflections on the origin and spread of nationalism. Revised edition. London/New York: Verso. [First edition 1983.]

Ansah, Paul A.V.

1986

'The struggle for rights and values in communication', in: Michael Traber (ed.), The myth of the information revolution, pp. 64-83. London: SAGE Publications. [SAGE Communications in Society series.]

Arps, Bernard 2003

'Letters on air in Banyuwangi (and beyond); Radio and phatic performance', Indonesia and the Malay World 31:301-16.

Auslander, Philip

1999 Liveness; Performance in a mediatized culture. London/New York: Routledge.

Bakhtin, M.M.

1981

The dialogic imagination; Four essays by M.M. Bakhtin. Edited by Michael Holquist. Translated by Caryl Emerson and Michael Holquist. Austin: University of Texas Press. [University of Texas Press Slavic Series 1.]

1984a Problems of Dostoevsky's poetics. Edited and translated by Caryl Emerson. Minneapolis: University of Minnesota Press. [Theory and History of Literature 8.]

1984b Rabelais and his world. Translated by Hélène Iswolsky. Bloomington: Indiana University Press. [A Midland Book 341.]

Barker, Joshua

2003

'Interkom in Indonesia; Not quite an imagined community', in: James T. Siegel and Audrey R. Kahin (eds), Southeast Asia over three generations; Essays presented to Benedict R.O'G. Anderson, pp. 383-96. Ithaca, NY: Cornell University Press. [Studies on Southeast Asia 36.] 
Benjamin, Walter

1977 Das Kunstwerk im Zeitalter seiner technischen Reproduzierbarkeit; Drei Studien zur Kunstsoziologie. Tenth edition. Frankfurt am Main: Suhrkamp Verlag. [First edition 1955.]

Bodden, Michael H.

1993

Imagining the audience as agent of its own history; Brecht, grassroots theater and representations of interclass alliance in the Philippines and Indonesia. $\mathrm{PhD}$ thesis, University of Wisconsin, Maddison.

Brecht, Bertolt

1978a ['Kritik der "Poetik" des Aristoteles'], in: Heinz Geiger and Hermann Haarmann (eds), Aspekte des Dramas, pp. 161-2. Opladen: Westdeutscher Verlag. [First published 1967.]

1978b 'Über experimentelles Theater', in: Heinz Geiger and Hermann Haarmann (eds), Aspekte des Dramas, pp. 163-5. Opladen: Westdeutscher Verlag. [First published 1939.]

1978c '(Vierter) Nachtrag zur Theorie des "Messingkaufs", in: Heinz Geiger and Hermann Haarmann (eds), Aspekte des Dramas, pp. 166-8. Opladen: Westdeutscher Verlag. [First published 1940.]

1993 'The radio as an apparatus of communication', in: David Strauss and Dave Mandl (eds), Radiotext(e), pp. 15-7. New York: Semiotext(e). [Semiotext(e) 16; First published 1932.]

Browne, Donald R.

1978 'International broadcasting to Asia', in: John A. Lent (ed.), Broadcasting in Asia and the Pacific; A continental survey of radio and television, pp. 31838. Hong Kong: Heinemann Asia.

Calhoun, Craig

1992 'Introduction; "Habermas and the public sphere"', in: Craig Calhoun (ed.), Habermas and the public sphere, pp. 1-48. Cambridge, MA/London: MIT Press. [Studies in Contemporary German Social Thought.]

Cook, Timothy E.

1998 Governing with the news; The news media as a political institution. Chicago/ London: University of Chicago Press.

Creese, Helen 2004

'Reading the Bali Post; Women and representation in post-Suharto Bali', Intersections. http://wwwsshe.murdoch.edu.au/intersections/ issue10/creese.html (accessed 2-3-2006). Article moved to http://intersections.anu.edu.au/issue10/creese.html (accessed 23-7-2009).

Dayan, Daniel and Elihu Katz

1992 Media events; The live broadcasting of history. Cambridge, MA/London: Harvard University Press.

Derks, Will 2004

'A literary mycelium; Some prolegomena for a project on Indonesian literatures in Malay', in: Timothy P. Barnard (ed.), Contesting Malayness; Malay identity across boundaries, pp. 181-202. Singapore: Singapore University Press. 
Foulcher, Keith

1993 'Post-modernism or the question of history; Some trends in Indonesian fiction since 1965', in: Virginia Matheson Hooker (ed.), Culture and society in New Order Indonesia, pp. 27-47. Kuala Lumpur: Oxford University Press. [South-East Asian Social Science Monographs.]

Fraser, Colin and Sonia Restrepo Estrada

2001 Buku panduan radio komunitas. Jakarta: UNESCO Jakarta Office.

Gazali, Effendi

2002a 'Dari editor', in: Effendi Gazali (ed.), Penyiaran alternatif tapi mutlak; Sebuah acuan tentang penyiaran publik dan komunitas, pp. viii-xi. Jakarta: Jurusan Ilmu Komunikasi FISIP, Universitas Indonesia.

2002b 'Memahami perbedaan lembaga penyiaran publik dan komersial', in: Effendi Gazali (ed.), Penyiaran alternatif tapi mutlak; Sebuah acuan tentang penyiaran publik dan komunitas, pp. 33-51. Jakarta: Jurusan Ilmu Komunikasi FISIP, Universitas Indonesia.

2002c 'Beberapa potensi kerancuan lain', in: Effendi Gazali (ed.), Penyiaran alternatif tapi mutlak; Sebuah acuan tentang penyiaran publik dan komunitas, pp. 52-69. Jakarta: Jurusan Ilmu Komunikasi FISIP, Universitas Indonesia.

2002d 'Mencoba memetakan dunia penyiaran kita dengan adanya lembaga penyiaran publik dan komunitas', in: Effendi Gazali (ed.), Penyiaran alternatif tapi mutlak; Sebuah acuan tentang penyiaran publik dan komunitas, pp. 84-95. Jakarta: Jurusan Ilmu Komunikasi FISIP Universitas Indonesia.

2002e 'Antara lembaga penyiaran publik dan komunitas', in: Effendi Gazali (ed.), Penyiaran alternatif tapi mutlak; Sebuah acuan tentang penyiaran publik dan komunitas, pp. 70-83. Jakarta: Jurusan Ilmu Komunikasi FISIP, Universitas Indonesia.

Global FM

2001 'Global FM 99,15 Kinijani Bali news letter; Edisi khusus HUT ke-2, 30 Mei 2001'. Newsletter, Global FM, Tabanan.

2002 'Radio Global 99,15 FM Bali; Edisi khusus HUT ke-3, 30 Mei 2002'. Newsletter, Global FM, Tabanan.

Habermas, Jürgen

1989a The structural transformation of the public sphere; An inquiry into a category of bourgeois society. Translated by Thomas Burger. Cambridge, MA: MIT Press. [Originally published as Strukturwandel der Öffentlichkeit. Darmstadt: Luchterhand, 1962.]

1989b Jürgen Habermas on society and politics; A reader. Edited by Steven Seidman. Boston: Beacon Press. [Selections translated from the German.]

Hae, Nur Zain, Rusdi Marpaung and Hawe Setiawan

$2000 \quad$ Konflik multikultur; Panduan meliput bagi jurnalis. Jakarta: LSPP.

Hale, Julian

1975 Radio power; Propaganda and international broadcasting. Philadelphia: Temple University Press.

Hasibuan, Imran and Sitok Srengenge (eds)

1996

Bredel di udara; Rekaman radio $A B C, B B C, D W$ Nederland, VoA. Jakarta: ISAI. 
Hefner, Robert W.

2000 Civil islam; Muslims and democratization in Indonesia. Princeton/Oxford: Princeton University Press.

Heryanto, Ariel

1996 'Bahasa dan kuasa; Tatapan posmodernisme', in: Yudi Latif and Idi Subandy Ibrahim (eds), Bahasa dan kekuasaan; Politik wacana di panggung Orde Baru, pp. 94-103. Bandung: Mizan.

Hidayat, Dedy N.

2002 'Neo liberalisme dan market dictatorship dalam industri penyiaran; Argumen bagi lembaga penyiaran publik', in: Effendi Gazali (ed.), Penyiaran alternatif tapi mutlak: Sebuah acuan tentang penyiaran publik dan komunitas, pp. 4-18. Jakarta: Jurusan Ilmu Komunikasi FISIP, Universitas Indonesia.

Hikam, Muhammad A.S.

1996 Demokrasi dan civil society. Jakarta: LP3ES.

Hill, David T.

1995 The press in New Order Indonesia. Jakarta: Sinar Harapan. [Originally published under the same title. Nedlands: University of Western Australia Press, 1994.]

Hill, David T. and Krishna Sen

1997 'Wiring the warung to global gateways; The Internet in Indonesia', Indonesia 63:67-89.

2005 The Internet in Indonesia's new democracy. London/New York: Routledge.

Hjarvard, Stig

1998 'TV news exchange', in: Oliver Boyd-Barrett and Terhi Rantanen (eds), The globalization of news, pp. 202-26. London: SAGE Publications.

Hodge, Errol

1995 Radio wars; Truth, propaganda and the struggle for Radio Australia. Cambridge: Cambridge University Press.

Holquist, Michael

1984 'Prologue', in: M.M. Bakhtin, Rabelais and his world, pp. xiii-xxiii. Bloomington: Indiana University Press. [A Midland Book 341.]

Howell, Jude and Jenny Pearce

2001 Civil society and development; A critical exploration. Boulder/London: Lynne Rienner Publishers.

Hutcheon, Linda

1989 The politics of postmodernism. London/New York: Routledge.

Indrianto, Antonius M.

2001 'Sekali di udara, lebih banyak di lapangan!'. Paper, UNESCO seminar 'Radio komunitas; Untuk demokrasi dan kesatuan bangsa', Yogyakarta, 4 September.

Jonathans, Errol

2000 'Jurnalistik radio', in: Layla S. Mirza (ed.), Politik dan radio; Buku pegangan bagi jurnalis radio, pp. 33-106. [Jakarta]: Friedrich Naumann Stiftung.

2006 Socrates di radio; Esai-esai jagad keradion. Yogyakarta: GongPlus. 
Jurriëns, Edwin

2003 'Radio komunitas di Indonesia; "New Brechtian theatre" di era Reformasi?', Antropologi Indonesia 72:116-30.

2004 Cultural travel and migrancy; The artistic representation of globalization in the electronic media of West Java. Leiden: KITLV Press. [Verhandelingen 216.]

2006 'Radio awards and the dialogic contestation of Indonesian journalism', Indonesia and the Malay World 34:119-49.

2007 'Indonesian radio culture; Modes of address, fields of action', Review of Indonesian and Malaysian Affairs (RIMA) 41-1:33-71.

2008 'Television dreams; Simulation, for a new reality of Indonesia', in: Ariel Heryanto (ed.), Popular culture in Indonesia; Fluid identities in post-authoritarian politics, pp. 143-63. London/New York: Routledge. [Routledge Media, Culture and Social Change in Asia 15.]

Jurriëns, Edwin and Jeroen de Kloet (eds)

2007 Cosmopatriots; On distant belongings and close encounters. Amsterdam/ New York: Rodopi. [Thamyris Intersecting; Place, Sex, and Race 16.]

Kartika, Sandra and Ida Rosdalina

1999

Konvensi tentang penghapusan segala bentuk diskriminasi terhadap perempuan. Jakarta: LSPP.

Kitley, Philip

2000 Television, nation, and culture in Indonesia. Athens, $\mathrm{OH}$ : Ohio University Center for International Studies. [Research in International Studies, Southeast Asia Series 104.]

2002 'Televisi bangsa baru; Television, Reformasi and renewal in Indonesia', Media International Australia 104:92-106.

2003 'Civil society in charge? Television and the public sphere in Indonesia after Reformasi', in: Philip Kitley (ed.), Television, regulation and civil society in Asia, pp. 97-114. London: Routledge Curzon.

Kleden, Ignas

1996

'Pemberontakan terhadap "narasi besar"; Membaca teks Putu Wijaya dengan pendekatan tekstual', in: Yudi Latif and Idi Subandy Ibrahim (eds), Bahasa dan kekuasaan; Politik wacana di panggung Orde Baru, pp. 318-41. Bandung: Mizan.

Kurasawa, A.

1987

'Propaganda media on Java under the Japanese 1942-1945', Indonesia 44:95-128.

Latif, Yudi and Idi Subandy Ibrahim (eds)

1996 Bahasa dan kekuasaan; Politik wacana di panggung Orde Baru. Bandung: Mizan.

Lewis, Peter M. and Jerry Booth

1989 The invisible medium; Public, commercial and community radio. Basingstoke: Macmillan Education.

Lindsay, Jennifer

1997

'Making waves; Private radios and local identities in Indonesia', Indonesia 64:105-23. 
Livingstone, Sonia and Peter Lunt

1994 Talk on television; Audience participation and public debate. London/New York: Routledge.

Loven, Klarijn

2003 Si Doel and beyond; Discourse on Indonesian television in the 1990s. PhD thesis, Universiteit Leiden, Leiden. [Published as Watching Si Doel; Television, language, and cultural identity in contemporary Indonesia. Leiden: KITLV Press, 2008. Verhandelingen 242.]

Maier, H.M.J. 1993

'From heteroglossia to polyglossia; The creation of Malay and Dutch in the Indies', Indonesia 56:37-65.

2004 We are playing relatives; A survey of Malay writing. Leiden: KITLV Press. [Verhandelingen 215.]

Mardianto, Herry and Antonius Darmanto

$2001 \quad$ Tradisi sastra Jawa radio. Yogyakarta: Kalika.

Masduki

2001

2003 Radio siaran dan demokratisasi. Yogyakarta: Jendela.

$2004 \quad K e b e b a s a n$ pers dan kode etik jurnalistik. Yogyakarta: UII Press.

Matheson Hooker, Virginia

1993 (ed.) Culture and society in New Order Indonesia. Kuala Lumpur: Oxford University Press. [South-East Asian Social Science Monographs.]

1996

McDaniel, Drew O.

'Bahasa dan pergeseran kekuasaan di Indonesia; Sorotan terhadap pembakuan bahasa Orde Baru', in: Yudi Latif and Idi Subandy Ibrahim (eds), Bahasa dan kekuasaan; Politik wacana di panggung Orde Baru, pp. 56-76. Bandung: Mizan.

1994 Broadcasting in the Malay world; Radio, television, and video in Brunei, Indonesia, Malaysia, and Singapore. New Jersey: Ablex.

McGoldrick, Annabel and Jack Lynch

$2001 \quad$ Jurnalisme damai; Bagaimana melakukannya? Jakarta: LSPP.

McPhail, Thomas L.

1987 Electronic colonialism; The future of international broadcasting and communication. Newbury Park: SAGE Publications. [SAGE Library of Social Research 126.]

Middleton, Richard

$1990 \quad$ Studying popular music. Milton Keynes/Philidelphia: Open University Press.

Mohamad, Goenawan

1993

Mora

2001
'Kesusastraan, pasemon', in: Goenawan Mohamad (author), Kesusastraan dan kekuasaan, pp. 117-28. Jakarta: Firdaus

'Bio data Mora FM 88.65; PT Radio Mora parna kasa'. Brochure, Mora, Bandung. 
Morris, Pam (ed.)

1994 The Bakhtin reader; Selected writings of Bakhtin, Medvedev, Voloshinov. London: Edward Arnold.

Mrázek, Jan

1999

'Javanese wayang kulit in the times of comedy; Clown scenes, innovation, and the performance's being in the present world; Part one', Indonesia 68:38-128.

Mrázek, Rudolf

2002

Engineers of happy land; Technology and nationalism in a colony. Princeton: Princeton University Press.

Muis, H.A.

1997

'Radio menyongsong abad 21', Radio; Majalah khusus 23 tahun PRSSNI Tingkat Jawa Barat 1997, pp. 23-5.

Muted voices

1996

'Muted voices; Censorship and the broadcast media in Indonesia'. Report, Article 19, London.

Nasir, Akhmad

2001 'Radio sebagai alat penguatan komunitas'. Paper, UNESCO seminar 'Radio komunitas; Untuk demokrasi dan kesatuan bangsa', Yogyakarta, 4 September.

Nugroho, Garin

2002

'Pengantar; Televisi untuk publik', in: Garin Nugroho (ed.), TV publik; Menggagas media demokratis di Indonesia, pp. vii-viii. Jakarta: Yayasan Sains Estetika dan Teknologi.

Nurdiana, Titis and Andreas Berthoni

2002 'Trik Soetojo menyiasati berita jadi informasi', Kontan 21(25 February):21.

Pabottinggi, Mochtar

1996 'Bahasa, kramanisasi, dan kerakyatan', in: Yudi Latif and Idi Subandy Ibrahim (eds), Bahasa dan kekuasaan; Politik wacana di panggung Orde Baru, pp. 154-69. Bandung: Mizan.

Pandjaitan, Hinca I.P.

2002 'Aspek hukum lembaga penyiaran komunitas', in: Effendi Gazali (ed.), Penyiaran alternatif tapi mutlak; Sebuah acuan tentang penyiaran publik dan komunitas, pp. 144-52. Jakarta: Jurusan Ilmu Komunikasi FISIP, Universitas Indonesia.

Pandjaitan, Hinca I.P., C.C. Chan, L.S. Schramm and L.N. Tabing (eds)

$2000 \quad$ Radio; Pagar hidup otonomi daerah. Jakarta: Internews Indonesia Media Law Department.

Pease, Edward C. and Everette E. Dennis (eds)

1995 Radio; The forgotten medium. New Brunswick/London: Transaction Publishers.

Peraturan Pemerintah

2005a Peraturan Pemerintah Republik Indonesia Nomor 11 Tahun 2005 tentang Penyelenggaraan Penyiaran Lembaga Penyiaran Publik. Legislative document, Government of Indonesia, Jakarta. 
Peraturan Pemerintah Republik Indonesia Nomor 12 Tahun 2005 tentang Lembaga Penyiaran Publik Radio Republik Indonesia. Legislative document, Government of Indonesia, Jakarta.

2005c Peraturan Pemerintah Republik Indonesia Nomor 13 Tahun 2005 tentang Lembaga Penyiaran Publik Televisi Republik Indonesia. Legislative document, Government of Indonesia, Jakarta.

PUSKAT

2001a

$2001 b$

$2001 c$

2001d

Radio awards

2000a

2001
'Paket liburan sekolah'. Brochure, PUSKAT, Yogyakarta.

'Puskat audio visual studio; Center for production training and cultural resort'. Brochure, PUSKAT, Yogyakarta.

'Training komunikasi 2001'. Brochure, PUSKAT, Yogyakarta.

'Wisata alternatif 2001'. Brochure, PUSKAT, Yogyakarta.

'Karya pemenang radio awards 2000 dengan tema: Wakil kita di DPR'. Audio-cassette with recordings of awarded programmes, Friedrich Naumann Stiftung, Jakarta.

'Radio awards 2000/Lomba program radio; Kategori reportase, mini feature dan wawancara'. Brochure, Friedrich Naumann Stiftung, Jakarta.

'Radio program awards 2001/Lomba program radio; Kategori mini feature, reportase, interview'. Brochure, Friedrich Naumann Stiftung, Jakarta.

Rahardja, Prathama and Henry Chambert-Loir

1990 Kamus bahasa prokem. Second edition. Jakarta: Pustaka Utama Grafiti. [First edition 1988.]

Robbins, Bruce

1998

'Introduction part 1; Actually existing cosmopolitanism', in: Pheng Cheah and Bruce Robbins (eds), Cosmopolitics; Thinking and feeling beyond the nation, pp. 1-20. Minneapolis/London: University of Minnesota Press.

Romano, Angela

$2003 \quad$ Politics and the press in Indonesia; Understanding an evolving political culture. London/New York: RoutledgeCurzon.

2005 'Asian journalism; News, development and the tides of liberalization and technology', in: Angela Romano and Michael Bromley (eds), Journalism and democracy in Asia, pp. 1-15. London/New York: Routledge.

Samuel, Jérôme

2002 'Radios Indonésiennes; Comment survivre à l'Ordre Nouveau?', Archipel 64:289-321.

Schulte Nordholt, Henk

2002 'Introduction', in: Henk Schulte Nordholt and Gusti Asnan (eds), Indonesia in transition; Work in progress, pp. 1-24. Yogyakarta: Pustaka Pelajar.

Schultz, Julianne

1998

Reviving the Fourth Estate; Democracy, accountability and the media. Cambridge: Cambridge University Press. [Reshaping Australian Institutions.] 
Schwarz, Adam

$2004 \quad$ A nation in waiting; Indonesia's search for stability. Singapore: Talisman. Seligman, Adam B.

1992 The idea of civil society. Princeton: Princeton University Press.

Sen, Krishna

2003 'Radio days; Media-politics in Indonesia', The Pacific Review 16:573-89.

Sen, Krishna and David T. Hill

2000 Media, culture and politics in Indonesia. Melbourne: Oxford University Press.

Siegel, James T.

1986 Solo in the New Order; Language and hierarchy in an Indonesian city. Princeton: Princeton University Press.

2001 'Suharto, witches', Indonesia 71:27-78.

Siregar, Ashadi

2002 'TV Publik; Sisi lain agenda Reformasi', in: Garin Nugroho (ed.), TV publik; Menggagas media demokratis di Indonesia, pp. 3-11. Jakarta: Yayasan Sains Estetika dan Teknologi.

Spyer, Patricia

2002 'Fire without smoke and other phantoms of Ambon's violence; Media effects, agency, and the work of imagination', Indonesia 74:21-36.

2005 'Media and violence in an age of transparency; Journalistic writing on war-torn Maluku', in: Birgit Meyer and Annelies Moors (eds), Religion, media, and the public sphere, pp. 152-65. Bloomington: Indiana University Press.

Spyer, Patricia, Ben Arps, Edwin Jurriëns, Katinka van Heeren and Wiwik Sushartami 2002 'Indonesian mediations; The re-imagining and re-imaging of community(s) in transition', in: Henk Schulte Nordholt and Irwan Abdullah (eds), Indonesia in search of transition, pp. 177-206. Yogyakarta: Pustaka Pelajar.

Stam, Robert

1989 Subversive pleasures; Bakhtin, cultural criticism and film. Baltimore/ London: John Hopkins University Press.

Steele, Janet

2005

Wars within; The story of 'Tempo', an independent magazine in Soeharto's Indonesia. Jakarta: Equinox Publishing; Singapore: Institute of Southeast Asian Studies.

Strassler, Karen

2004 'Reformasi through our eyes'; Children as witnesses of history in post-Soeharto Indonesia'. Paper, Conference 'Media and the making of history in post-Suharto Indonesia', Leiden University, Leiden, 9-10 December.

Suara Surabaya

2002

'Suara Surabaya FM 100.55; Kepercayaan warga Surabaya'. Brochure, Suara Surabaya, Surabaya. 
Sunjaya, Mohamad

1996 'Prakata; Dari hobi mendengar radio', in: Imran Hasibuan and Sitok Srengenge (eds), Bredel di udara; Rekaman radio $A B C, B B C, D W$ Nederland, VoA, pp. v-viii. Jakarta: ISAI.

Suryadi

2005

'Identity, media and the margins; Radio in Pekanbaru, Riau (Indonesia)', Journal of Southeast Asian Studies 36:131-51.

Suryakusuma, Julia I.

2004 Sex, power and nation; An anthology of writings, 1979-2003. Jakarta: Metafor Publishing.

Suryawan, I Nugrah

2005 'Dari "pariwisata budaya" ke "Ajeg Bali" (beberapa perspektif perubahan wacana politik kebudayaan dan seni di Bali pasca rezim Soeharto)'. Paper, workshop 'Arts, culture and political and social change since Suharto', University of Tasmania, Launceston, 16-18 December.

Swara Gadjah Mada

2001 'PT. Radio Swara Gadjah Mada 98,45 MHz Yogyakarta'. Brochure, Swaragama, Yogyakarta.

Syah, Sirikit

$2000 \quad$ 'Tokoh pers 1999; Media watch', Kompas, 6 January.

http://www.kompas.com/kompas-cetak/0001/06/opini/toko04.htm

Tabing, Louie N. (accessed 20-12-2005).

2000 'Bagian keempat; Radio swadaya masyarakat, bentuk baru komunikasi di Asia', in: Hinca I.P. Pandjaitan, C.C. Chan, L.S. Schramm and L.N. Tabing (eds), Radio; Pagar hidup otonomi daerah, pp. 127-38. Jakarta: Internews Indonesia Media Law Department.

Teeuw, A.

1994 Modern Indonesian literature. Vol. 1. Fourth edition. Leiden: KITLV Press. [Translation Series 10; Originally published under the same title. The Hague: Nijhoff, 1967.]

Tobing, Sumita

1991 Development journalism in Indonesia; Content analysis of government television news. PhD thesis, Ohio University. Athens, $\mathrm{OH}$.

Undang-Undang

$1998 \quad$ Undang-Undang Republik Indonesia Nomor 9 Tahun 1998 tentang Kemerdekaan Menyampaikan Pendapat di Muka Umum. Legislative document, Government of Indonesia, Jakarta.

$2002 \quad$ Undang-Undang Republik Indonesia Nomor 32 Tahun 2002 tentang Penyiaran. Legislative document, Government of Indonesia, Jakarta.

Vatikiotis, Michael R.J.

1993 Indonesian politics under Suharto; Order, development and pressure for change. London/New York: Routledge. [Politics in Asia series.]

Warren, Carol

$1994 \quad$ Centre and periphery in Indonesia; Environment, politics and human rights in the regional press (Bali). Murdoch: Asia Research Centre at Murdoch University. [Working paper 42.] 
'Tanah Lot; The cultural and environmental politics of resort development in Bali', in: Philip Hirsch and Carol Warren (eds), The politics of environment in Southeast Asia; Resources and resistance, pp. 229-61. Lon-

Weintraub, Andrew don/New York: Routledge.

2001

'Contest-ing culture; Sundanese wayang golek purwa competitions in New Order Indonesia', Asian Theatre Journal 18:87-104.

2004 Power plays; Wayang golek puppet theatre of West Java. Athens, OH: Ohio University Research in International Studies. [Southeast Asia Series 110.]

Wild, Colin

'Indonesia; A nation and its broadcasters', Indonesia Circle 43:15-40.

1991

'The radio midwife; Some thoughts on the role of broadcasting during the Indonesian struggle for independence', Indonesia Circle 55:34-42.

Witoelar, Wimar

1997 'Lessons from "Perspektif"', in: Bhimanto Suwastoyo (ed.), Broadcasting in Asia, pp. 155-60. [Jakarta]: Alliance of Independent Journalists and Institute for the Studies on Free Flow of Information.

Witte, René

1998 De Indische radio-omroep; Overheidsbeleid en ontwikkeling, 1923-1942. Hilversum: Verloren.

Wolters, Willem

2002

'The making of civil society in historical perspective', in: Henk Schulte Nordholt and Irwan Abdullah (eds), Indonesia in search of transition, pp. 131-48. Yogyakarta: Pustaka Pelajar.

Yampolsky, Philip

1995 'Forces for change in the regional performing arts of Indonesia', Bijdragen tot de Taal-, Land-en Volkenkunde 151:700-25.

Zimmer, Benjamin G.

1998

'The New dis-Order; Parodic plésétan and the 'slipping' of the Soeharto regime', Antara Kita; Bulletin of the Indonesian Studies Committee of the Association for Asian Studies 54(July):4-9.

\section{Personal communications}

Arya Dikara (I Gusti Ngurah Dibia), Tabanan, 10-7-2002.

Billy M. Sobirin, Jakarta, 3-10-2001.

Dani, Yogyakarta, 29-8-2001.

Darpan A. Winangun, Jakarta, 10-10-2001.

Errol Jonathans, Surabaya, 24-7-2002.

Firqie Firmansyah, Jakarta, 15-8-2002.

Fred Wibowo, Yogyakarta, 31-8-2001.

Idham Hamid, Padang, 20-8-2002.

Ido Seno, Jakarta, 12-10-2001.

Kecuk Sahana, Yogyakarta, 30-8-2001.

Layla S. Mirza, Bandung, 28-9-2001. 
Louis C. Schramm, Jakarta, 18-9-2001.

Masduki, Yogyakarta, 4-9-2001.

Meinara Iman D., Surabaya, 24-7-2002.

Mustawar Lubis, Padang, 20-8-2002.

Nor Pud Binarto, Jakarta, 11-8-2001.

Santoso, Jakarta, 18-10-2001.

Surowo Haryono, Yogyakarta, 2-8-2002.

Taye Tayudin Dj., Bandung, 27-9-2001.

Veven Sp. Wardhana, Jakarta, 18-10-2001.

Wibowo, Yogyakarta, 31-8-2001.

Yuga, Yogyakarta, 3-9-2001.

Yusirwan Yusuf, Padang, 19-8-2002.

Audio sources

Global FM

2002a 'Global terkini', Tabanan, 11-7-2002.

2002b Jingle 'Bali terkini', Tabanan, 11-7-2002.

2002c Jingle 'Global FM', Tabanan, 10-7-2002.

2002d Jingle 'Global FM', Tabanan, 11-7-2002.

IMLPC, Indonesia Media Law and Policy Centre

2001a 'Mengawal kebebasan pers; Bagaimana mengenali wartawan dengan benar', Jakarta, August 2001.

2001b 'Mengawal kebebasan pers; Kekerasan terhadap media massa oleh massa', Jakarta, June 2001.

2001c 'Mengawal kebebasan pers; Siapa yang bertanggung jawab dalam sebuah talk show', Jakarta, June 2001.

Jakarta News FM

2001a 'Features sang guru', Jakarta, 15-9-2001.

2001b Jingle 'Jakarta News FM', Jakarta, 16-10-2001.

2001c 'Ngobrol sama Dono', Jakarta. [weekly episodes 2001.]

2001d 'Sabtu bersama Ratna', Jakarta, 20-10-2001.

KBR 68H, Kantor Berita Radio 68H

2000 'MPR tetap pertahankan TNI/Polri hingga 2009'. Mini-feature for FNS

'Radio awards 2000'.

2001 'Hak asasi manusia', Jakarta, 9-10-2001.

2002a Jingle 'Agama dan toleransi', Jakarta, 14-8-2002.

2002b Jingle 'Kabar baru', Jakarta, 14-8-2002.

Mora

2001a Jingle 'Mora', Bandung. [daily episodes 2001.]

2001b 'Kasasi', Bandung, 29-9-2001.

2001c 'Mora interaktif', Bandung, 27-9-2001. 
2001d 'Saksi', Bandung, 29-9-2001.

2001e 'Somasi', Bandung, 4-10-2001.

Radio $68 \mathrm{H}$

2002

'Sikap redaksi Radio Berita 68H', Jakarta, 14-8-2002.

SCFM

2002a

Jingle 'Dunia bisnis Indonesia', Surabaya, 25-7-2002.

$2002 b$

Jingle 'Thank God it's Friday', Surabaya, 26-7-2002.

Suara Padang

2002a

Jingle 'Kabar baru', Padang. [daily episodes 2002.]

$2002 b$

Jingle 'Suara Padang', Padang. [daily episodes 2002.]

Suara Surabaya

$2002 a$

'Kelana kota', Surabaya, 23-7-2002.

$2002 b$

'Lembaga konsumen media', Surabaya, 23-7-2002.

Trijaya

2001a

'Jakarta first channel', Jakarta, 16-10-2001.

$2001 b$

'Thank God it's Friday', Jakarta, 19-10-2001. 